\title{
Knowledge Management Capabilty to Organizational Innovation Study at Indonesia Islamic Banking
}

\author{
Ariesta Heksarini \\ Fakultas Ekonomi dan Bisnis, Universitas Mulawarman \\ Samarinda, Indonesia \\ ariesta.heksarini@feb.unmul.ac.id
}

\begin{abstract}
Innovation is the success key to increasingly business competition. Innovation plays an important role to the competitive advantages. Companies must have the ability to quickly innovate and sustainable grow in order to win the competition. The development of Islamic banking is an interesting phenomenon in recent years. As newly emerging business, the future success of sharia system depends on the ability to present attractive and competitive products and provide various transactional to convenience people needs. It has problems in developing knowledge are expected to be identified and resolved through this research. This study focuses on strategies for applying knowledge management to improve organizational innovation on Islamic banking in Indonesia. Previous studies are conducted in different industry and the scarcity in the context of organizational innovation of Islamic banking also as a gap that underlies this research. This research is a type of literature research study by reference theory to describe and analyze the observation data.

Result - Islamic banking in Indonesia should provide human resources with the ins and outs of Islamic banking itself. Leaders needed in Islamic banking in Indonesia should be reliable in managing financial banking, also be a role model in sharia sciences and facilitate the organization learning process in order to create valuable human resources in the dynamic environment. It can be stated that improving Indonesia's Islamic banking organizational innovation can only be done through the strategic implications of knowledge management.
\end{abstract}

Keywords - Organizational Innovation; Organizational Learning; Knowledge Management Capability; Human Resource Practice; Transformational Leadership.

\section{BACKGROUND}

The existence of banking is a reflection of the Muslim majority population needed in Indonesia over the banking system that can contribute stability to the national financial system. The Islamic banking industry also reflects the demand of people who need an alternative banking system that provides banking services that comply with the principles of Islamic (Machmud and Rukmana, 2010: 59). Indonesia as known as a country that has the largest Muslim population in the world with the number based on 2010 BPS data of 180 million people. This condition is a good prospect for the development of Islamic banking in the future.

Unlike conventional banking relationships of creditors, or time value of money, Islamic banking focuses on partnerships by observing Islamic law (sharia) that exclude interest (riba), significant uncertainty (Ghara) and speculation (Maysir). According to Islamic principles, Islamic banks also expect a balance of financial benefits with social responsibility (Haron and Hisham, 2003 in Matt Elbeck, Evangellos-Vagelis Dedoussis, 2010). From the operational side, public funds in the form of deposits and new investments will get the results if cultivated first, while in conventional banks, public funds in the form of savings to be paid interest at maturity. On the channelling side, Islamic banks channel their funds to halal and profitable business sectors, while in conventional banking this is not a major consideration. With such uniqueness, the current Islamic banking sector has grown quite rapidly in the world, and especially in Indonesia in the last decade.

Growth in terms of volume of Islamic banking business, fund raising, institutional development, as well as capital and earnings has exceeded conventional banking. Institutionally, the Islamic banking network increased to 11 Islamic Unit Entities (BUS), with a total office network of 1,688 offices and 1,277 office chanelling. From the fundraising side there was an increase of $52.79 \%$ from Rp. 66.48 trillion in 2010 to Rp. 101.57 trillion in 2011 (Bank Indonesia, Islamic Banking Outlook 2012).

The high growth of Islamic banking in Indonesia was not matched by adequate supply of labor in this sector. The lack of supply and demand has caused a lot of labor in Islamic banking with conventional 
banking background, which in turn leads to a lack of human resources who really understand about the ins and outs of Islamic banking. The absence of Islamic human resource curriculum standards compiled among universities leads to the lack of qualifications for college graduates to meet the human resource needs of Islamic banks.

Based on the description of various problems above, the authors are interested to further explore and examine the problems in the sector of Islamic banking, especially on the issue of innovation.

\section{LITERATURE REVIEW}

\section{A. Organizational Innovation}

The varies definition of innovation found in the literature are common and broad, while others focus on specific innovations such as execution of ideas for new products or services. In an organizational environment, innovation is the implementation of ideas for restructuring, saving costs, improving communications, new technologies for production processes, new organizational structures and new personnel plans or programs (Kanter; 1983; West and Farr; 1990; Robbins 1996; In Martins, 2003).

West and Farr (1990) define innovation as: "Intentional introduction and application in a group, role or organization of ideas, processes, products or new procedures to relevant units, designed to provide individual, group, organizational or community benefits. "The context in which new ideas, products, services or activities are implemented determines whether it can be considered an innovation in a particular context (Martins, 2000, 2003).

Innovation often associated with change (Drucker, 1985) quoted in West and Farr, 1990; Robbins, 1996;. Hellriegel et al, 1998). Innovation seen as something new leads to change. However, change cannot always be considered as innovative because it does not involve new ideas or always lead to improvements in an organization (CIMA Text Study, 1996; West and Farr, 1990). An example of a change that cannot be considered as innovation changes in working hours in extremely hot weather. Innovation considered as a process, result, or both, and different types of innovation have been distinguished. According to these, innovation is the application of ideas or behaviors, which can be a new system, policy, program, device, process, product or service for the organization (Damanpour and Gopalakrishnan, 1998; Damanpour et al., 1989; Wolfe 1994, In Jimenez, et al., 2008).

This study focuses on the most frequently used dimensions of process innovation, product innovation and administrative innovation such as Oke, et. Al (2007), Jimenez (2008), and Iker Murat. Differences between products and processes relate to areas and activities that affect innovation (Gopalakrishnan and Damanpour, 1998).

\section{B. Knowledge Management}

Generally, Knowledge Management defined as a systematic management of knowledge processes through new knowledge created, identified, grouped, shared and applied. (Nonaka and Takeguchi, 1995) defines knowledge management as a dynamic human process in justifying personal beliefs in a Truth (Budiharjo,2011).

Knowledge management promotes an integrated approach to identifying, capturing, retrieving, sharing, and evaluating a company's information assets. This information asset may include databases, documents, policies and procedures, as well as the potential skills and experience not yet disclosed by each employee. (Gartner in Hicks, 2006)

Lin and Kuo (2007) found that human resource management policies or activities should be established to facilitate organizational learning activities and / or knowledge management skills; otherwise, positive effects on organizational performance cannot be achieved from policy or resource management activities only. Thus, to improve learning and knowledge management, executives should focus on formulating organizational learning policies and $\mathrm{KM}$ to be effective and facilitate their implementation.

Nonaka and Takeguchi (1995: 2009) describes the process of knowledge management as an ongoing process that is divided into four phases including knowledge application, knowledge acquisition, knowledge organization and knowledge dissemination. Ju et al., (2006) argues that organizational learning levels have a significant impact on knowledge integration, knowledge management skills, and enterprise innovation 
capabilities; Interaction effects from humanoriented knowledge management strategies, organizational learning, knowledge-oriented knowledge management systems and found knowledge integration will greatly impact knowledge management skills.

Based on the above description, the knowledge in this study is defined as a systematic activity or a process of identifying, capturing, managing and utilizing knowledge to enhance the organization's ability to create superior, growing and enduring products, services and new systems. The measurement dimension of knowledge management using Lin and Kuo (2007), and Kuo (2011) opinions:

- Acquisition of knowledge

- The dissemination of knowledge

- Interpret and develop knowledge

\section{Organizational Learning}

Organizational learning is the process of information acquisition, and information interpretation resulting behavioral and cognitive changes, also impacting the performance of the organization. Dimovski in Gorelick, (2005) Organization learning consists of four stages; intuition, interpreting, integrating and institutionalizing, the process has been widely adopted in related studies (Bontis, 2002)

Kang et al. (2007) suggests that firms need to develop strategies not only based on the core of knowledge and ability but must also work to acquire, transfer, and integrate new knowledge, facilitate organizational learning processes to create valuable human capital needed in dynamic environment. Organizational learning has been regarded as a routine-based, and target-oriented (Levitt and March, 1988, in Lin and Kuo, 2008).

Based on the above definition, organizational learning in this study is an ongoing process of knowledge creation, acquisition, as a routine transformation to acquire, distribute, integrate, and create information and knowledge among members of the organization.

Model of organizational learning measurement in this research is adapted from research of Lin and Kuo (2007) with dimension as follows:

- Information dissemination mechanism

- Climate created in the company
- Application of learning systems and methods

- Achievements expected

\section{Human Resource Pratice}

Experts have defined different in human resource management, but basically have the same essence. Stoner (2006) argues that "human resource management is an ongoing procedure aimed at supplying an organization or company with the right people to be placed in the right position and position when the organization needs it." Mathis and Jackson (2004) ) states "Human Resource Manage -ment is an administrative operation that deals with payroll, employee history, and social visit arrangements."

Some opinions in more detail on the activities in human resource management subsequently proposed by Flippo in Handoko (2001) as "Activities of planning, organizing, directing and human oversight within the organization." In line with this Schuler and Jackson (2004) "Activities planning humans, selection of personnel, assessment option, compensation, and training and development. "Then Dessler (2009)," the process of obtaining, train, assess and compensate the employee, pay attention to their working relationship, health, security and justice issues. "

Nonetheless human resource management contains elements of human management within the organization. It can be stated that human resource management is an organizational function that includes ongoing activities such as recruiting, filtering, training, appraising, rewarding, maintaining and terminating employment as part of efforts to achieve organizational, individual and community goals.

Schuler and Jackson (1987) considers the choice of human planning, staffing choices, choice assessments, compensation options, and training and development as the five key dimensions associated with competitive strategy. Gupt and Singhal (1993) share the four dimensions of HRM Practice concepts, including human resource planning, performance appraisal system awards, and career management. Gomez et al., (1998) classifies, in detail, the functions of human resource management into nine dimensions that include workflow, staffing, lay-off management, 
performance evaluation, training and development, management compensation, the relationship between employee empowerment and internationalization. Based on the above literature, the authors quote Lin and Kuo (2008) in classifying human resource management into five factors including assessment, staff training, and development, workflow, and rewards and compensation.

\section{E. Transformational Leadership}

The concept of leadership drew high attention from social scientists over the last few decades. In the 1980s, management researchers became deeply interested in the emotional and symbolic aspects of leadership. This process helps us to understand how leaders influence followers to try to put mission needs or organizational goals ahead of personal or group

interests.

Transformational Leadership is the last thought of effective leadership delivered by a group of experts who try to "revive" the "trait theory" or the person main traits possesses in order to become a leader. Robert House conveys leadership theory by suggesting that effective leadership uses dominance, has self-confidence, influences and displays high morality to raise its charismatic level (Ivancevich et al., 2008: 213). Relying on charisma, a "transformational" leader always challenges his subordinates to give birth to special works. The steps taken in general are to talk with followers, how important their performance is, how proud and confident they are as a member of the group and how special the group can be to produce innovative and extraordinary work.

According to the founder of this theory, the "transformational" leader is very effective because it combines the two theories of "behavioral" and "situational" theories with their respective advantages. Integrating human-oriented behavioral patterns or in production with a review of the situation coupled with its charismatic strength. This type of transformational leader is ideally suited to dynamic organizations, concerned with change and innovation as well as competing closely with other companies within the international sphere. The main requirement of success is the presence of a leader with charisma. (Ivancevich, 2008: 214). A leader in this section combines elements of selfpower, authority possessed, personality traits and social skills to influence the employee behavior.

From these various descriptions, the transformational leadership in this study is a leadership behavior that influences its followers through values, attitudes, and beliefs to achieve higher motivation and morale to achieve established organizational goals. The indicator used is adapted from the research of Bass (1995) which divides transformational leadership into four dimensions:

- Charisma.

- Individual considerations.

- Intellectual stimulation.

- Inspiration

Based on the theoretical and empirical studies, the theoretical model constructed in this study is described as follows:

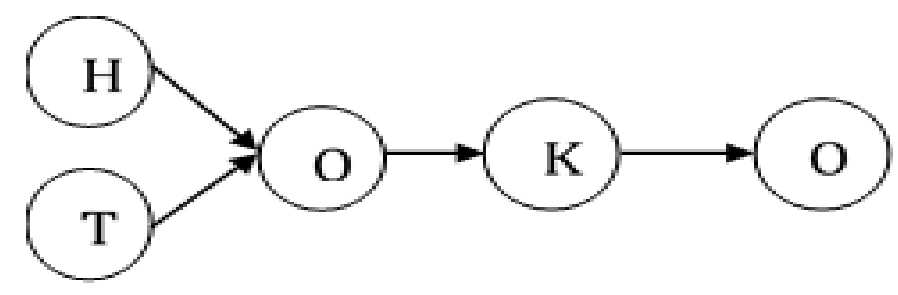

Empirical model

\section{THEORETICAL DISCUSSION}

\section{A. Organizational Innovation}

Fundamental changes in business and economic environments create high changes in competitive conditions and the world economy today. These changes include changes in the dynamic business environment, the uncertainty of the economy and business that is unpredictable, causing Indonesian Islamic banks have to adjust and innovate strategy to win the competition.

Utilizing a potential opportunity that $85 \%$ of Indonesia's population is Muslim, it is important today to combine efficiency, quality, flexibility and innovation for Islamic banking. Innovation is more than technical-organization, it also demands a social policy. Successful innovation means more than research and development; R \& D should be transformed into products and services sold in the market and cause value added to stakeholders. Adjustment between $\mathrm{R} \& \mathrm{D}$, production and 
marketing is very important which can lead to new product designs and work processes, offices and factories. Innovation is the process which valuable ideas are transformed into new forms of added value to organizations, customers, employees and stakeholders. The transformation process is now as a whole learning process for the organization to maintain continuity on the basis of innovation based on creativity.

Innovation is the success key of Indonesia's Islamic banking to be more competitive and faster growing in accordance with the people needs. The success of the Islamic banking system in the future depends on the ability of Islamic banks to present more attractive, diverse, competitive products and facilitate transactions, according to the people needs. Product innovation should be a priority strategy for Islamic banks, because innovation has an important role in a competitive marketplace. Therefore, the Islamic banking industry must be able to continue to make new innovations.

\section{B. Knowledge Management}

The process of knowledge management in Indonesian Islamic banking based on relationships and cooperation with experts from outside the company, it is seen from the implementation of systems and procedures overseen by the Sharia Supervisory Board (Dewan Pengawas Syariah). Another phenomenon of the condition can be seen from the establishment of cooperation between Islamic banks with universities and professionals in the field of Islamic economics, and the implementation of it to various informal mechanisms as an effort to improve the company's ability.

Furthermore, the activities of interpreting and developing the knowledge itself have been done and become a shared commitment through teamwork and sharing of knowledge and experience among employees, and up to date database of corporate clients. From this activity, Indonesia's Islamic banking has a form - the name in accordance with their respective fields - each so that can be found a concrete problem expert at any time.

In the process of information and knowledge dissemination to the lowest level of the company.
Indonesian Islamic banking has a formal mechanism that guarantees best practices among various fields of activity, including individual involvement or teamwork, the use of communication tools in the knowledge dissemination process (Nonaka et al. 2000), develops an integrated model of dynamic knowledge development. Know -ledge as a dynamic thing, because it is created in social interaction between individuals and organizations. Knowledge is a specific context, because it depends on a certain time and space. Without information into context, it's the same information, not knowledge. Information becomes knowledge when interpreted by individuals and is given context and anchored in individual beliefs and commitments (Nonaka et al., 2000).

\section{Human Resource Practice}

The practice of human resource management in Islamic banking should enable the formation of employee skills, abilities, values, beliefs, attitudes and behaviors, through recruitment, socialization and developing a recruitment pool. For example, providing training and development to employees, such as on-the-job training, job rotation, training, mentoring, case studies and others can help to improve employee knowledge, skills, experience, skills and motivation (Fong et al., 2011).

The human resource management function in sharia banking is manifested in recruitment and selection activities, training and development, career planning, performance appraisal, and remuneration. Preffer in Soetjipto (2006) argues that human resources are a source of competitive advantage that is "timeless by heat and undamaged by rain". He compares the position of other sources of excellence diminishing in value, such as technology and production processes. Thus, no matter how well the technology is used, the role of human resources in determining the success of Islamic Banking remains a success key in organizational activities.

It is undeniable that at this time the task of being a banker is still considered prestigious by the people of Indonesia, and became one of the professions coveted by job seekers despite different disciplinary background. This condition is actually 
an advantage for Indonesian Islamic banking in determining the classification of employees as what the company wants in the selection of employees, given the large interest and breadth of the recruitment pool limitations.

Clear performance appraisals related to promotion are the most representative indicators of human resource management practices in Islamic banking in Indonesia, making employees very concerned and focused on achieving excellence in employment, as motivation to achieve high scores in performance appraisal conducted.

Similarly, training and development activities are demanding by all employees, most of the training is in an effort to prepare employee promotion to a new duties or positions that are not mastered. The interest and enthusiasm of employees to follow every activity and training clearly understood the purpose.

In terms of income received by employees indicate this condition still needs to be considered. The nature of an employee as a human being who is often overwhelmed with feelings of dissatisfaction and wants to earn higher than whatever has been earned at this time, especially when compared with the greater income of others, coupled with the rising prices of necessities, causes this phenomenon as natural and likely will continue to happen.

The implementation of teamwork, should be able to involve all employees in turn without exception in self-managed groups related to the preparation of strategies and policies that aligned with the business environment. Employee involvement in teamwork should not be limited by a less objective factor and will impact on social inequalities. Of course, the involvement of employees in the management of the company will also affect the development of skills and competence of employees, as well as the success of the company.

\section{Transformational Leadership}

The leader of Indonesian Islamic banking should not only show a charismatic figure in having amazing abilities and skills for employees and ideal behavior to set aside personal interest and role model for employees, but also have built employee's confidence, support energetically and self-development, as well as more grounded or humanize its employees.

Meanwhile, the attention of the leadership in the form of direct communication to employees, and leaders who are able to stimulate the intellectual and inspire are considered less representative in explaining transformational leadership in Indonesia's Islamic banking. Direct communication from the leaders to employees in daily formal or non-formal meetings as a support form and encouragement that builds employee confidence. It has a positive impact in finding the task completion tips.

In relation to this matter, the figure of Indonesian Islamic bank leadership is not enough to only generate high learning spirit for the employees, but also appreciate and treat subordinates as a whole person, including listening to the complaints of its employees.

\section{E. Organizational Learning}

The learning process con -ducted through regular meetings and using the mentoring and open discussion system on the problems occurred. It has also greatly supported to the creation of know ledge for of Indonesia's Islamic banking employees. The process of disseminating information and achievement of each employee in working at the last rank.

Dissemination of information from management should be ascertained on time to the lowest level employees. This can be done in stages according to the organizational structure, and may further inform competitors about the management. Employees should also get the desired atmosphere and valuable experience in each training, as well as clarity of duties to be able to manage their own work schedules.

\section{IV.CONCLUSION}

Human resource management and transformational leadership strategies resulting in better organizational learning and knowledge management skills, ultimately contributing to organizational innovation.

In order for effectively knowledge management and properly implemented afor the Indonesian Islamic Banking, the main principles are as follows: 
- The importance of the of Sharia Banking managers / leader's role in making all employees understand how clear vision and strategy by utilizing knowledge management to developing the organization.

- Islamic banking needs the support of technology capabilities in creating comfort and accessibility, support for acquisition of knowledge from within and outside the organization, including storage, dissemination and application of knowledge to organizations to enable knowledge management in goals achieving, as well as a combination of knowledgeable employees with commitment and determination to learning, to bring knowledge in developing and solving problems in their work.

- Islamic Bankers / managers must motivate and create a learning culture, exchange and share knowledge through various activities, seminars, group activities and teamwork, which require constant and constant effort.

- Management of the organization, application of knowledge in work procedures and responsibilities of Islamic Banking employees should be conducive encouraged as a continuous and serious process.

- Islamic banking should be able to improve and develop the competence of its employees to start best practices including improving the organization's competitive ability.

Human resource management practices in Islamic Banking should shape employee skills, abilities, values, beliefs, attitudes and behaviors through proper recruitment, socialization and recruitment pool developing. For example, providing training and development to employees, such as on-the-job training, job rotation, training as needed, mentoring, case studies and others can help to improve employee knowledge, skills, experience, skills and motivation.

The most representative trans -formational leadership is a charismatic leader and has ideal behavior that can be used as a priority in an effort to improve organizational learning. Mean -while, leaders attention to employees as well as the ability of stimulating intellectuals to be an inspiration can be used as an alternative effort to encourage organizational learning in Indonesia's Islamic Banking.

Organizational learning should be undertaken by every individual in Islamic Banking. Individual learning occurs when a person acquires knowledge through education, experience or experimentation as a routine to acquire, distribute, integrate, and create information and knowledge among members of the organization. Organizational learning in Islamic Banking is formed when organizational systems and cultures are concerned with learning and transferring new ideas to all employees.

\section{REFERENCES}

[1] Adegoke Oke, (2007), "Innovation Types and Innovation Management Practices in Service Companies", International Journal of Operations \& Production Mana -gement, Vol. 27 Iss: 6 pp. $564-587$

[2] Agustianto, 2011, Meningkatkan Kompetensi SDM Syariah.http://www.agustiantocentre.com/?p=445, accessed 1 Mei 2012.

[3] Aujirapongpan,Somnuk, Pakpachong Vadhanasindhu, Achara Chandrachai, Pracob Cooparat, 2010, "Indicators of Knowledge management capability for KM effectiveness", VINE, Vol. 40 Iss: 2, pp. $183-203$.

[4] Baljeet, KaurGrewal, 2012, Internationalizationof Islamic Finance, Malaysia.

[5] Bontis, Nick, 2002, The Strategic Management of Intellectual Capital and Organizational Learning, Oxford University Press.

[6] Budiharjo, Andreas, 2011, Organisasi : Menuju Pencapaian Kinerja Optimum. Jakarta: Prasetya Mulya Publishing.

[7] Dessler, Garry. 2000, Human ResourceManagement, New Jersey Prentice Hall International Inc., 8th Edition.

[8] Direktorat Perbankan Syariah, Outlook PerbankanSyariah Indonesia 2011.

[9] Elbeck, M, Evangellos-Vagelis Dedoussis, 2010, "Arabian Gulf Innovator Attitudes for Online IslamicBank Marketing Strategy", Journal of Islamic Marketing, Vol. 1 Iss: 3 pp. $268-285$.

[10] Fong, Chee-Yang, Keng-Boon Ooi, Boon-In Tan, Voon-Hsien Lee, Alain Yee-Loong Chong, 2011, "HRM Practicesand Knowledge Sharing: an Empirical Study", International Journal of Manpower, Vol. 32 Iss: 5

[11] Gomez, Faustino Cardoso, 2003, Manajemen Sumber Daya Manusia. Yogyakarta : Andi Offset.

[12] Gorelick, Carol, 2005, "Organizational Learning vs The Learning Organization: a Conversation with aPractitioner", The Learning Organization, Vol. 12 Iss: 4 pp. $383-388$.

[13] Hicks,Richard C, Ronald Dattero, Stuart D. Galup, 2006, "The Fivetier Knowledge Management Hierarchy",Journal of Knowledge Management, Vol. 10 Iss: 1, pp.19-31.

[14] Iker Murat Ar, Birdogan Baki, (2011),"Antecedents and performance impacts of product versus process innovation: Empirical evidence from SMEs located in Turkish science and technology parks", European Journal of Innovation Management, Vol. 14 Iss: 2pp. 172 - 206

[15] Daniel Jiménez-Jimenez, Raquel Sanz Valle, Miguel HernandezEspallardo, (2008),"Fostering innovation: The role of market orientation and organizational learning", European Journal of Innovation Management, Vol. 11 Iss: 3 pp. $389-412$

[16] Ju, Teresa L. Chia-Ying Li, Tien-Shiang Lee, 2006, "A Contingency Model for Knowledge Management Capability and Innovation", Industrial Management \& Data Systems, Vol. 106 Iss: 6, pp.855 - 877.

[17] Kuo, Tsung-Hsien, 2011, "How to Improve Organizational Performance Through Learning and Knowledge?",International Journal of Manpower, Vol. 32 Iss: 5/6, pp.581 - 603. 
[18] Lin, Chin-Yen, Tsung-Hsien Kuo, 2007, "The Mediate Effect of Learning and Knowledge on Organizational Performance", Industrial Management \& Data Systems, Vol. 107 Iss: 7, pp.1066 - 1083.

[19] López, Álvaro - Cabrales, Juan C. Real, Ramón Valle, 2011, "Relationships Between Human Resource Management Practices and Organizational Learning Capability: The Mediating Role of Human Capital", Personnel Review, Vol. 40 Iss: 3, pp.344 - 363.

[20] Lopez, S.V., 2005, "Competitive Advantage and Strategy Formulation: The Key Role of Dynamic Capabilities", Management Decision, Vol. 43 No.5, pp.661-9.

[21] Machmud, Amir \& H. Rukmana, 2010, Teori, Kebijakan, dn Studi Empiris di Indonesia, Erlangga, Jakarta

[22] Mathis, Robert L \& John H Jackson, 2006, Human Resource Management, alih bahasa. Salemba Empat. Jakarta.

[23] Mohamed, M., Stankosky, M., Murray, A., 2006, "Knowledge Management and Information Technology: Can They Work in Perfect
Harmony?",Journal of Knowledge Management, Vol. 10 Iss: 3, pp.103 -11 .

[24] Nonaka, I., Toyama, R., Konno, N., 2009, "SECI, BA and Leadership: a Unified Model of Dynamic Knowledge Creation", Long Range Planning, Vol. 33 pp.4-34.

[25] Schuler, Randall S \& Susan E Jackson, 2007, Human Resource Management Strategy, second edition, Wiley.

[26] Stoner, A.F., 2006, Manajemen Sumber Daya Manusia (translate), Jakarta: Bumi Aksara.

[27] Wang, Dong, Zhongfeng Su, Dongtao Yang, 2011, "Organizational culture and knowledge creation capability", Journal of Knowledge Management, Vol. 15 Iss: 3 pp. 363 - 373.

[28] Yukl, Gary, 1998, Kepemimpinan Dalam Organisasi (translate), Jakarta , Prenhallindo. 